\title{
PERAN ORANGTUA SEBAGAI FUNGSI RELIGIUS DALAM MENCEGAH PERILAKU SEKS BEBAS DI KALANGAN REMAJA DI KELURAHAN PASAR HILIR
}

\author{
${ }^{1}$ Nurhasanah Pardede, ${ }^{2}$ Ahmad Rasyid Pulungan \\ Prodi Bimbingan dan Konseling, Universitas Muhammadiyah Tapanuli Selatan \\ nurhasanah.pardede@um-tapsel.ac.id
}

\begin{abstract}
The objectives of this study were: To determine the level of knowledge of free sex behavior of adolescents in Pasar Hilir Village, to determine the role of parents as a religious function in preventing adolescent free sex behavior in Pasar Hilir Village. The scope of this research is: Free sex behavior in Pasar Hilir Urban Village, the role of parents as a religious function in Pasar Hilir Village. This research uses qualitative research. Qualitative research is a research method used to examine the condition of a natural object, where the researcher is the key instrument. The data collection technique is done by triangulation (combined), namely making observations (observations), interviews (interviews), documentation studies and a combination of the three. Based on the results of the research obtained from the results of interviews with informants to determine the role of parents in preventing free sex behavior, namely parents provide spiritual flush by calling ustadz to provide explanations to their children so that their children know the dangers and impacts of free sex behavior. bad for their future, the impact they will feel is that the first is always unsettled by what they have done out there, the second becomes silent because they are afraid that their actions will be discovered.
\end{abstract}

Keywords: Role of Parents, Religious Functions, Free Sex Behavior.

\begin{abstract}
Abstrak:Tujuan penelitian ini adalah: Untuk mengetahui tingkat pengetahuan perilaku seks bebas yang dimiliki remaja di Kelurahan Pasar Hilir, Untuk mengetahui peran orangtua sebagai fungsi religius dalam mencegah perilaku seks bebas remaja di Kelurahan Pasar Hilir. Ruang lingkup penelitian ini adalah: Perilaku seks bebas di Kelurahan Pasar Hilir,Peran Orangtua sebagai fungsi religius di Kelurahan Pasar Hilir. Pada penelitian ini digunakan jenis penelitian kualitatif. Penelitian kualitatif yaitu metode penelitian yang digunakan untuk meneliti pada kondisi obyek yang alamiah, dimana peneliti sebagai instrument kunci. Teknik pengumpulan data dilakukan secara triangulasi (gabungan) yaitu melakukan observasi (pengamatan), interview (wawancara), studi dokumentasi dan gabungan dari ketiganya. Berdasarkan hasil penelitian di peroleh dari hasil wawancara peneliti dengan informan untuk mengetahui sampai dimana peran orangua dalam mencegah perilaku seks bebas yaitu para orangtua memberikan siraman rohani dengan memanggil ustadz memberikan penjelasan kepada anak-anak mereka supaya anak-anaknya mengetahui bahaya dan dampak perilaku seks bebas yang berakibat buruk bagi masa depan mereka,dampak yang akan meraka rasakan adalah yang pertama itu selalu merasa resah dengan apa yang sudah mereka lakukan diluar sana, yang kedua menjadi pendiam karena mereka takut perbuatan mereka diketahui.
\end{abstract}

Kata Kunci: Peran Orangtua, Fungsi Religius, Perilaku Seks Bebas.

\section{PENDAHULUAN}

Orang tua merupakan figur penting

dalam kehidupan seorang remaja. Relasi dan peran orang tua pada masa remaja sangat penting bagi perkembangandiri remaja
(Gunarsa, 2004: 27). Relasi yang baik antara orang tua dan remaja yang telah dibina sejak lahir akan menimbulkan adanya keterikatan atau ikatan relasi satu sama lain. mengemukakan bahwa keterikatan adalah 
hubungan, mengembangkan interaksi antara orang tua dan anak. Relasi atau hubungan orang tua dengan anak remaja pada keluarga normal terlihat adanya afeksi yang hangat antara orang tua terhadap anak remaja dan remaja terhadap orangtua.

Berdasarkan laporan hasil Survei Mitra Remaja (MCR) jawa barat, terdapat delapan faktoryang mempengaruhi terjadinya seks bebas remaja, di antaranya faktor sulit mengendalikan dorongan seksual menduduki peringkat tertinggi $63,68 \%$, selanjutnya factor kurang taat agama55,79\%, ransangan seksual 52,63\%, sering nonton blue film $49,47 \%$, tidak ada bimbingan orang tua $9,47 \%$, pengaruh tren $24,74 \%$, tekanan dari lingkungan $18,42 \%$, dan masalah ekonomi $12,11 \%$.

Pendapat tersebut diperkuat dengan berdasarkan hasil penelitian dalam skripsi Desi Mustika (2015) Universitas Negeri Semarang tentang "Meningkatkan Pengetahuan Pendidikan Seks Melalui Layanan Informasi Siswa Kelas VI MIN Sumurrejo Kota Semarangtahun 2015/2016" dapat diambil kesimpulan sebagai berikut: tingkat pengetahuan siswa sebelum mendapatkan Layanan informasi tergolong dalam katagori rendah dengan persentase $39 \%$ menjadi $75 \%$ dalam kategori tinggi. Dengan demikian mengalami peningkatan sebesar $36 \%$.

Berdasarkan hasil pra-penelitian yang di lakukan pada Bulan Oktober 2019tersebut pada remaja di Kelurahan
Pasar Hilir menyatakan bahwa sebagian tidak dapat menjelaskan tentang dampak seks bebas, perilaku seks bebas, faktorfaktor yang mempengaruhi terjadinya seks bebas,dan cara penanggulangan seks bebas.

Dari uraian di atas, peneliti sangat tertarik untuk mengetahui permasalahan tersebut dan ingin mengungkapnya dalam penelitian ilmiah, dengan mengambil judul "Peran Orangtua Sebagai Fungsi Religius Dalam Mencegah Perilaku Seks Bebas di Kalangan Remaja di Kelurahan Pasar Hilir".

\section{METODE}

\section{Teknik dan Alat Pengumpulan Data}

Jenis penelitian kualitatif dengan metode studi kasus.Dalam penelitian ini teknik pengumpulan data yang digunakan peneliti adalah sebagai berikut:

1. Observasi (Observation )yaitu: Observasi partisipatif, Observasi terus terang atau tersamar,

2. Wawancara (Interview) yaitu: Wawancara Terstruktur (Structured Interview), Wawancara Semiterstruktur (Semistructure Interview), Wawancara Tak Berstruktur (Unstructured Interview).

3. Studi Dokumentasi

\section{Responden dan Informan Penelitian}

Responden Penelitian merupakan subyek penelitian dengan karakteristik :

1) Peran Orangtua di Kelurahan Pasar Hilir. 
2) Faktor Penyebab Perilaku Seks Bebas di Kelurahan Pasar Hilir.

3) Dampak Perilaku Seks Bebas di Kelurahan Pasar Hilir.

Tabel 1 Responden Penelitian

\begin{tabular}{|l|l|l|}
\hline No & Responden & \multicolumn{1}{|c|}{ Keterangan } \\
\hline \multirow{4}{*}{1.} & \multirow{3}{*}{ Orangtua } & Nama : SH \\
& & Usia : 49 \\
& & Jenis Kelamin : \\
& & Laki-Laki \\
\cline { 3 - 4 } & & Nama : SM \\
& & Usia : 50 \\
& & Jenis Kelamin : \\
& & Laki-Laki \\
\hline
\end{tabular}

\section{Teknik Analisis Data}

Menurut Sugiyono dalam Iskandar (2009:221), "Analisis data kualitatif adalah proses mencari dan menyusun secara sistematis data yang diperoleh dari hasil pengamatan (observasi), wawancara, catatan lapangan, dan studi dokumentasi dengan cara mengorganisasikan data ke sintesis, menyusun ke dalam pola, memilih mana yang penting dan mana yang akan dipelajari dan membuat kesimpulan sehingga mudah dipahami oleh diri sendiri maupun orang lain”.

1. Triangulasi terdiri dari yaitu: Triangulasi Sumber, dan Triangulasi Teknik.

2. Analisis Tematik

Keabsahan dan Keajegan Penelitian.

\section{HASIL}

1. Peran Orangtua Sebagai Fungsi Religius Dalam Mencegah Perilaku Seks Bebas Pada Remaja
Sebelum peneliti melakukan wawancara peneliti terlebih dahulu melakukan data observasi. Adapun hasil observasi peneliti sebagai berikut:

Peneliti melihat Peran Orangtua Sebagai Fungsi Religius Dalam Mencegah Perilaku Seks Bebas Pada Remaja sudah sangat marak di lurah saya melakukan melakukan penelitian para remaja sudah banyak yang melakukan perilaku seks bebas dan para orangtua sangat di butuhkan perannya untuk lebih dominan dalam mengawal keseharian anak.

Orang tua adalah komponen keluarga yang terdiri dari ayah dan ibu dan merupakan hasil dari sebuah ikatan perkawinan yang sah dan membentuk suatu keluarga." Orang tua yang sesungguhnya memiliki tugas yang sangat berat karena harus bertanggung jawab untuk mendidik, mengasuh dan membimbing anakanaknya untuk mencapai tahapan tertentu yang menghantarkan anak untuk siap dalam kehidupan bermasyarakat.

Religius merupakan dorongan jiwa seseorang yang mempunyai akal, dengan kehendak dan pilihannya sendiri mengikuti peraturan tersebut guna mencapai kebahagiaan dunia akhirat. Sedangkan menurut Zakiyah Darajat dalam psikologi agama dapat difahami religius merupakan sebuah perasaan, pikiran dan motivasi yang mendorong terjadinya perilaku beragama.

Hal ini mencakup pemujaan atau ibadah, ketaatan, dan hal-hal yang dilakukan orang untuk menunjukkan komitmen terhadap agama yang dianutnya. Dimensi ini mencakup perilaku 
ibadah, ketaatan, dan hal-hal yang dilakukan orang untuk menunjukkan komitmen atau tingkat kepatuhan muslim terhadap agama yang dianutnya menyangkut pelaksanaan shalat, puasa, zakat, haji. Praktik keagamaan ini terdiri dari dua kelas penting yaitu ritual dan ketaatan.

Perilaku seks bebas merupakan suatu perilaku yang tidak dapat dihindari dalam kehidupan kita sehari-hari, perilaku seks bebas merupakan hal yang penting dalam berbagai pola tindakan manusia sebagai makhluk sosial, artinya manusia hidup saling berdampingan satu sama lain saling membutuhkan. Hubungan antar manusia akan menimbulkan perilaku seks bebas antar remaja.

Dimana tujuan dalam penelitian untuk melihat fungsi religius orangtua dalam hal mencegah perilaku seks bebas ini sangat bagus karena di lurah ini orangtua sangat membimbing anak-anak mereka ke arah yang lebih baik agar tidak terjerumus kepada hal-hal yang negatif seperti perilaku seks bebas, dan para orangtua juga mengarahkan anak-anaknya untuk mengikuti kegiatan pengajian pada malam hari agar tidak sering keluar pada malam hari untuk menghindari perilaku seks bebas ini.

Fungsi religius yang diberikan orangtua terhadap para remaja ataupun anak-anaknya fungsi religius yang seperti siraman rohani dari ustad agar diberi pencerahan bahwa apa yang mereka lakukan itu adalah salah dan bisa membuat masa depan mereka hancur, dan orangtua juga selalu membimbing anak diruamah agar tidak terjadi hal yang tidak diinginkan seperti perilaku seks bebas ini.

\section{Keterbatasan Penelitian}

$$
\text { Penelitian yang telah dilakukan }
$$

memberikan gambaran tentang peran orangtua sebagai fungsi religius terhadap perilaku seks bebas remaja tersebut, para orangtua harus bisa meningkatkan pemahaman remaja tentang perilaku seks bebas sangat penting agar remaja tidak terjerumus kepada hal-hal yang lebih berat lagi. Namun dalam pelaksanaan penelitian, terdapat beberapa keterbatasan, penelitian yaitu:

1) Penelitian ini hanya menggambarkan tentang kurangnya peran orangtua dalam memberikan perhatian terhadap anak maupun remaja dan memberikan pengawasan terhadap keseharian anak. Dengan demikian, diharapkan bagi peneliti lain untuk dapat melanjutkan tentang variabel penelitian ini dikaitkan dengan variabel lainnya.

2) Kajian penelitian ini difokuskan pada dua hal, yaitu:

(1) Perilaku seks bebas di Kelurahan Pasar Hilir.

(2) Peran Orangtua sebagai fungsi religius di Kelurahan Pasar Hilir.

(3) Remaja yang dimaksud adalah remaja dengan rentan usia 17 tahun yang masih duduk di bangku sekolah (SMA/SMK/MA).

\section{SIMPULAN}

Berdasarkan hasil penelitian tentang peran orangtua sebagai fungsi religius dalam mencegah perilaku seks bebas pada remaja, maka dapat ditarik kesimpulan sebagai berikut: 
1. Pentingnya peran orangtua sebagai fungsi religius terhadap perkembangan remaja agar tidak terkena dampak perilaku seks bebas yang berada di Kelurahan Pasar Hilir. Dari yang saya lihat selaku orangtua karakteristik anak-anak itu tidak bisa kita lihat karena mereka bisa menyembunyikan perbuata mereka dari orangtua mereka sehingga para anak-anak ataupun remaja kita selaku para orangtua tidak bisa mengetahui apakah karakteristik anak kita yang bemacam-macam apakah meraka sudah melakukan perilaku seks bebas diluar sana, makana dari itu saya selaku orangtua meminta kepada ibu peneliti memberikan cara untuk mengetahuinya.

2. Dampak yang akan di terima oleh remaja itu kedepannya sangat banyak karena sudah melakukan perilaku seks bebas ini dimana dampak yang akan meraka rasakan adalah yang pertama itu selalu merasa resah dengan apa yang sudah mereka lakukan diluar sana, yang kedua menjadi pendiam karena mereka takut perbuatan mereka diketahui maka dari itu remaja yang sudah terkena perilaku seks bebas akan selalu mereka tidak enak dengan perasaannya.

karakter dari para remaja saya lihat dalam keseharian mereka biasa saja dan kita tidak mengetahui mana yang sudah terkena dalam perilaku seks bebas dan mana yang tidak terkena jadi saya menyimpulkan untuk perilaku sek bebas ini mereka para remaja bisa menyembnyikan karakter mereka agar perbuatan mereka tidak diketahui oleh para orangtua.

\section{DAFTAR RUJUKAN}

Gunarsa, 2003. Ciri Umum Masa Remaja. Rohima Press: Yogyakarta.

Harun Nasution, 2001. Psikologi Perkembangan, Suatu Pendekatan Sepanjang Rentan Kehidupan. Jakarta : Erlangga.

Sugiyono. 2008. Metode Penelitian Pendidikan Pendekatan Kuantitatif, kualitatif, dan R\&D. Bandung : Alfabeta.

Suharsimi Arikunto, 2006. Prosedur Penelitian Suatu Pendekatan Praktek. Raneka Cipta : Jakarta.

Sumadi Suryabrata, 2004. Faktor-Faktor Perkembangan Remaja. Jakarta : Raja Grafindo

Thoha, 2004. Kepemimpinan Dalam Manajemen. PT Raja Grafindo Persada: Jakarta. 